\title{
Design of steel sheathed cold-formed steel framed shear walls
}

\author{
N. Balh ${ }^{1}$, J. DaBreo ${ }^{1}$, C. Ong-Tone ${ }^{1}$, K. El-Saloussy ${ }^{1}$, C. $\mathrm{Yu}^{2}$ and C.A. Rogers ${ }^{1 *}$ \\ ${ }^{1}$ Department of Civil Engineering, McGill University, Montreal, Canada \\ ${ }^{2}$ Department of Engineering Technology, University of North Texas, Denton, USA
}

*Corresponding author

Tel. 514 398-6449

Fax.514 398-7361

colin.rogers@mcgill.ca

Dept. of Civil Engineering

McGill University

Macdonald Engineering Building

817 Sherbrooke Street West

Montreal, QC, Canada, H3A 0C3 


\begin{abstract}
A method for the design of steel sheathed cold-formed steel framed shear walls has been developed for inclusion in the American Iron and Steel Institute’s North American standards for lateral design using a comprehensive database of single-storey shear wall tests carried out in Canada and in the United States. The wall configurations differed in terms of wall aspect ratio, framing and sheathing thickness, screw fastener schedule and framing reinforcement. The equivalent energy elastic-plastic (EEEP) analysis approach was used to derive key design information from the test data, including; nominal shear resistance, a resistance factor, an overstrength factor for capacity based seismic design and 'test-based' seismic force modification factors for ductility and over-strength.
\end{abstract}

Keywords : shear wall, design, cold-formed steel, lateral loading, panel, connections. 


\section{Introduction}

At present, the design in North America of light framed shear walls constructed of cold-formed steel (CFS) components falls under the jurisdiction of the American Iron and Steel Institute's (AISI) S213 Standard [1]. However, to improve on the usability and clarity of this existing standard its contents are to be reassigned to two new AISI standards that are currently in development. The AISI S240 North American standard for cold-formed steel structural framing [2] will include, among other aspects, the design of lateral load carrying systems for wind and low seismic loading, while the AISI S400 North American standard for seismic design of coldformed steel structural systems [3] will address high seismic concerns. Moreover, the two new standards are to be established to improve on the efficiency and the practicality of incorporating upgraded design provisions for cold-formed steel systems and new lateral framing systems into a codified format available to practicing engineers. A lateral framing system for which improvement to the design process is warranted is the screw connected steel sheathed CFS framed shear wall. The existing AISI S213 design provisions for the USA and Mexico are limited to a few wall configurations (combinations of member thickness, sheathing thickness and sheathing connection pattern), while no design provisions are available for Canada. This limitation in design information severely restricts the capability of engineers to specify and design these all-steel shear walls. As such, there is a need to develop design provisions for a greater range of steel sheathed shear walls, with the intent of including the resulting design method in the new AISI S240 and S400 standards.

A design method for wood sheathed CFS framed shear walls was developed [4] and incorporated into AISI S213; the approach taken in the development of this existing design method, which is reliant on information gained from the testing of representative shear wall assemblies [5,6], can 
also be used to establish a design method for steel sheathed shear walls (Fig. 1a). In earthquake resistant design of light framed shear walls, the sheathing-to-framing screw connections act as the fuse device that dissipates seismic energy through inelastic deformations. The use of thin steel sheathing in-place of wood structural sheathing is expected to modify the behaviour of a shear wall due to the difference in material and thickness properties of the sheathing and the behaviour of the sheathing screw fasteners under load; thus, separate design information is required. A database of CFS framed steel sheathed shear wall tests was first generated by combining the results of laboratory based research programs in Canada [7-11] and in the United States [12-14]. The test programs comprised wall specimens that varied in aspect ratio, framing and sheathing thickness and screw fastener schedule/spacing. Additionally, included in the database were shear walls with special frame blocking reinforcement that were subjected to combined gravity and lateral loading.

The objective of the research described herein was to use this database of shear wall tests to develop a design method for steel sheathed CFS framed walls. The scope of research involved the application of the Equivalent Energy Elastic-Plastic (EEEP) method [15-17] to analyse the test data and to derive key design information [7-9, 18].

\section{Shear Wall Test Programs}

Data obtained from the test programs of single-storey steel sheathed shear wall assemblies carried out in Canada (Table 1) [7-10] and in the United States (Table 2) [12, 13] were combined to establish a database of information. The Canadian test program comprised two phases [10]; the first phase authored by Balh \& Rogers [8] and Ong-Tone \& Rogers [7] contained 54 test walls (18 configurations) subjected to displacement based monotonic and reversed cyclic lateral 
loading protocols, while the second phase included 14 shear walls (8 configurations) tested by DaBreo \& Rogers [9] under combined lateral and gravity loading, as depicted in Fig. 1b. The US test program also comprised two phases; the first was composed of 58 test walls (15 configurations) by Yu et al. [12] and the second phase included 35 test walls (13 configurations) by $\mathrm{Yu} \&$ Chen [13], all of which were tested under lateral displacement based monotonic and reversed cyclic loading. A brief summary of these two test programs is provided herein.

The first phase Canadian walls were of dimensions (aspect ratios) of $610 \mathrm{~mm} \times 2440 \mathrm{~mm}$ (4:1), $1220 \mathrm{~mm} \times 2440 \mathrm{~mm}(2: 1), 1830 \mathrm{~mm} \times 2440 \mathrm{~mm}(1.33: 1)$ and $2440 \mathrm{~mm} \times 2440 \mathrm{~mm}(1: 1)$. The framing members and sheathing were of ASTM A653 [21] Grade 230 MPa steel. The studs (92.1 $\mathrm{mm}$ web, $41.3 \mathrm{~mm}$ flange and $12.7 \mathrm{~mm}$ lip) and tracks (92.1 mm web, $38.1 \mathrm{~mm}$ flange) were $0.84 \mathrm{~mm}$ or $1.09 \mathrm{~mm}$ thick, and were connected using No. $8 \times 12.7 \mathrm{~mm}$ wafer head self-drilling / self-tapping screws. Built-up back-to-back chord studs were used at the wall ends, while single field studs were spaced at $610 \mathrm{~mm}$ on-centre along the wall length where applicable. Simpson Strong-Tie S/HD10S hold-down devices were attached to both ends of each chord stud. The sheathing panels were either $0.46 \mathrm{~mm}$ or $0.76 \mathrm{~mm}$ nominal thickness and were attached to one side of the wall using No. $8 \times 19$ mm self-drilling / self-tapping pan head screws. The sheathing screws were placed $9.5 \mathrm{~mm}$ from the panel edge and spaced at $50 \mathrm{~mm}, 75 \mathrm{~mm}, 100 \mathrm{~mm}$ or 150 mm on-centre over the perimeter and at $300 \mathrm{~mm}$ on-centre along the field stud(s). A typical 1220 $\mathrm{mm} \times 2440 \mathrm{~mm}$ wall, sheathed with a single steel panel, is illustrated in Fig. 2a. The longer walls required two sheathing panels which were joined to a common field stud with a butt joint as shown in Fig. 2c. The walls $610 \mathrm{~mm}$ in length were only used to verify the shear resistance reduction factor $(2 w / h)$ for high aspect ratio walls specified in AISI S213 [1]. Modified wall 
configurations as documented in DaBreo et al. [10] were also excluded from the database since these specimens were constructed with variations from the standard test wall configurations.

Shear wall specimens with thick sheathing and closely spaced fasteners typically exhibited unfavourable twisting deformation damage to the chord studs due to tension field forces in the sheathing as described by DaBreo et al. [10] and as shown in Fig. 3b. To address this problem, a second phase of Canadian shear wall tests was carried out, which included 14 shear wall specimens with blocked framing (Fig. 2b \& 3a). The shear walls were $1220 \mathrm{~mm} \times 2440 \mathrm{~mm}$ (2:1) in size and of similar construction to the first phase walls but included special quarter point frame blocking elements, the same size and thickness as the track members, to restrain the chord studs from twisting. Capacity based design principles were used to select the chord stud thickness needed for each test wall configuration. This design procedure [10] ensured that the inelastic deformations of the wall under loading were restricted to the sheathing connections (Fig. 3c). These same blocked walls were also used in a suite of single and double storey specimens dynamically tested on a shake table to show their effectiveness under seismic loading [11].

The first phase of the US shear wall test program by Yu et al. [12] contained steel sheathed specimens that were constructed with an un-blocked frame. The walls were of sizes (aspect ratios) of $610 \mathrm{~mm} \times 2440 \mathrm{~mm} \mathrm{(4:1)}$ and $1220 \mathrm{~mm} \times 2440 \mathrm{~mm}(2: 1)$ and were constructed of 0.84 $\mathrm{mm}$ and $1.09 \mathrm{~mm}$ thick framing, $0.84 \mathrm{~mm}, 0.76 \mathrm{~mm}$ or $0.68 \mathrm{~mm}$ thick steel sheathing and screw fastener spacing of $50 \mathrm{~mm}, 100 \mathrm{~mm}$ and $150 \mathrm{~mm}$ on-centre over the panel perimeter and at 300 mm on-centre for field studs. The framing members and sheathing were of ASTM A1003 [22] Grade $230 \mathrm{MPa}$ steel. The studs (88.9 mm web, $41.3 \mathrm{~mm}$ flange and $12.7 \mathrm{~mm}$ lip) and tracks (88.9 mm web, $38.1 \mathrm{~mm}$ flange) were $0.84 \mathrm{~mm}$ or $1.09 \mathrm{~mm}$ thick, placed at $610 \mathrm{~mm}$ on-centre 
along the length of the wall. Double C-shaped studs (back-to-back) were used for both chord studs of the wall. Number $8 \times 12.7 \mathrm{~mm}$ modified truss head self-drilling / self-tapping screws were used to attach framing member tracks to studs. The steel sheathing was installed on one side of the wall with No. $8 \times 12.7 \mathrm{~mm}$ modified truss head self-drilling / self-tapping screws. A single steel panel was used for all walls. Simpson Strong-Tie S/HD10S hold-down devices were

placed at the base of the wall attached to the interior of the chord studs that were expected to undergo uplift. In the second phase of tests by Yu \& Chen [13] the stud members of some walls were supported by a single row of mid-height blocking elements with the aim of improving the wall's seismic performance and reducing the extent of twisting damage to chord studs as well as flexural damage to field studs. Full blocking was only placed between the chord studs and first field stud; the remaining field studs were supported with horizontal straps that were connected to the blocking, i.e. a construction detail in accordance with AISI S230 Section E [20]. The other details of the second phase US test specimens were the same as found for Phase 1 except that $1830 \mathrm{~mm} \times 2440 \mathrm{~mm}$ (1.33:1) walls were also included in the scope of study (with multiple sheathing panels), $0.46 \mathrm{~mm}$ thick sheathing was also used as was $1.37 \mathrm{~mm}$ thick framing, and only the sheathing screw perimeter spacing of 50 and $150 \mathrm{~mm}$ on-centre were considered. In addition, for increased shear resistance some of the walls were constructed with No. $10 \times 19.1$ mm self-drilling / self-tapping screws instead of No. 8 screws. Lastly, one wall configuration was constructed with $152 \mathrm{~mm}$ deep studs in place of the standard $88.9 \mathrm{~mm}$ studs.

\section{Evaluation of Design Information (EEEP Method)}

Branston et al. [4] presented a method in which information for the purpose of the design of wood sheathed CFS framed shear walls was obtained from shear wall test data following the 
Equivalent Energy Elastic-Plastic (EEEP) analysis approach. The resulting design information was later adopted for use in the Canadian section of AISI S213 [1], and will be transferred to the AISI S240 [2] and S400 [3] standards as they are developed. Furthermore, the seismic force modification R-values found in the 2010 National Building Code of Canada [23] for use with cold-formed steel shear walls constructed with wood sheathing were based, in part, on the EEEP analysis method [24]. Given that the loading response of the steel sheathed shear walls [10] is conceptually similar to their wood sheathed [5] counterparts, the same data analysis approach was implemented to obtain design information to be recommended for inclusion in the AISI S240 [2] and S400 [3] standards.

The EEEP analysis method incorporates an energy balance approach described by Park [15] which was subsequently modified by Foliente [16], and is also found in ASTM A2126 [17]. The method can be used to represent the behaviour of light framed shear walls subjected to either monotonic or reversed cyclic lateral in-plane loads. The analysis model results in an idealized resistance vs. deflection curve of a simple bilinear shape, as illustrated in Fig. 4, in which the dissipated energy of a shear wall measured during testing, i.e. the area under the monotonic resistance vs. deflection curve or backbone curve of a reversed cyclic test, is equivalent to that found under the bilinear curve, up to the level of the functional capacity which is defined at the $0.8 \mathrm{~S}_{\mathrm{u}}$ post-peak deflection $\Delta_{0.8 \mathrm{u}}$ (or rotation $\theta_{0.8 \mathrm{u}}$ ) [17]. Note in the case where $\Delta_{0.8 \mathrm{u}}$ exceeded the 2.5\% seismic inelastic drift limit [23] only the equivalent energy up to the drift limit was considered as per Branston et al. [4]. The elastic section of the EEEP curve is defined using the secant stiffness associated with the initial slope through $0.4 S_{u}$, where $S_{u}$ is the measured ultimate shear resistance, and the corresponding deflection $\Delta_{0.4 \mathrm{u}}$ (or rotation $\theta_{0.4 \mathrm{u}}$ ). The plastic portion of the curve denotes the nominal shear resistance $S_{y}$ used for the design of a wall. Examples of the 
resulting EEEP curves of typical monotonic and reversed cyclic shear wall tests are shown in Figs. 4 \& 5, respectively. Note, for each reversed cyclic test two separate bi-linear EEEP curves were obtained; one for each of the positive and negative displacement cycles.

\subsection{Effect of frame blocking reinforcement}

Due to torsional damage observed in the CFS chord studs (Fig. 3b), as well as flexural damage to field studs, of steel sheathed shear walls tested in both the US and Canada the phase two testing of the research programs contained walls with various types of frame reinforcement. Yu \& Chen [13] performed tests on shear walls constructed with mid-height blocking elements; this reinforcement reduced the extent of damage to the field studs compared with what had been observed in identical standard walls without blockings [12]. Additionally, there were increases to the shear resistance and initial elastic stiffness due to the blocking. A comparison of the nominal shear resistance values, $\mathrm{S}_{\mathrm{y}}$, of similarly constructed walls of $0.84 \mathrm{~mm}$ steel sheathing and $50 \mathrm{~mm}$ screw spacing, with and without the mid-height blockings (Table 3), showed an increase of 5.2\% and $14.9 \%$ for walls of aspect ratios $2: 1$ and $4: 3$, respectively.

The quarter-point blocked walls tested by DaBreo \& Rogers [9] were compared with the previously tested un-blocked walls of the same configuration tested by Ong-Tone \& Rogers [7] and Balh \& Rogers [8]. Nominally identical shear walls in terms of aspect ratio, sheathing and framing thickness, and screw spacing were grouped for comparison purposes. The damage to the chord studs due to the torsional load caused by the single sided sheathing was substantially reduced in the walls with quarter-point blocking [11]. The blocked walls reached higher shear resistance values both in terms of $S_{u}$ and $S_{y}$, as illustrated in Figs. 6 \& 7. The blocked walls also dissipated considerably more energy [11], mainly due to the higher shear resistance achieved. In contrast, the blocked walls attained lower ultimate failure displacements, $\Delta_{0.8 u}$, because of the 
higher rate of post-peak strength degradation, which can be attributed to the localization of damage under loading to the sheathing connections (Fig. 3c).

Due to the improved lateral resistance of the shear walls with reinforced framing members separate nominal shear resistance values were determined for the blocked (quarter-point) and unblocked construction details, as described in Section 3.2. However, since only a limited number of wall configurations were tested with mid-height blocking, i.e. $50 \mathrm{~mm}$ screw spacing and walls $1830 \mathrm{~mm}$ long, design values cannot be provided at this time.

\subsection{Nominal shear resistance values}

The data from each test wall were analysed using the EEEP approach to determine the nominal shear resistance, $\mathrm{S}_{\mathrm{y}}$. It was important to consider that these $\mathrm{S}_{\mathrm{y}}$ values were dependent on the failure of the sheathing screw connections by bearing deformations of the steel sheathing. Since the bearing resistance of a steel sheet is directly related to its thickness, $t$, and tensile strength, $F_{u}$, the ancillary coupon tests of the steel sheathing were relied on to demonstrate that these measured properties were higher than the nominal thickness and minimum specified tensile strength, respectively [10]. Hence, the $\mathrm{S}_{\mathrm{y}}$ shear resistance values for each test wall were reduced using modification factors for sheathing thickness and tensile strength such that the resulting nominal values were representative of a wall constructed with steel of nominal thickness and material strength. The modification factors were determined from the direct ratio of nominal / measured thickness and minimum specified / measured tensile strength [7-9, 18].

The shear wall specimens from the two test programs $[7-10,12,13]$ were then grouped based on the nominal values of sheathing thickness, framing thickness and screw fastener spacing to 
obtain a nominal design shear resistance for a particular wall configuration by means of an average $\mathrm{S}_{\mathrm{y}}$ value. The results from the corresponding monotonic and reversed cyclic tests, when available, were combined in these groupings. In doing so, it was necessary to consider that each reversed cyclic test provided two values for $\mathrm{S}_{\mathrm{y}}$ (Fig. 5). A 0.5 weighting factor was placed on the reversed cyclic $\mathrm{S}_{\mathrm{y}}$ values when determining the average shear resistance for each particular wall configuration such that a reversed cyclic test and a monotonic test were of equal influence on the final recommended design value. The proposed shear resistance design values are presented in Table 4 for configurations composed of $0.46 \mathrm{~mm}, 0.68 \mathrm{~mm}, 0.76 \mathrm{~mm}$ and $0.84 \mathrm{~mm}$ sheathing. Note, the $75 \mathrm{~mm}$ sheathing fastener spacing design values were developed using a straight line interpolation between the $100 \mathrm{~mm}$ and $50 \mathrm{~mm}$ screw spacing configurations when test data were not available. Although the design values obtained were for walls constructed of approximately $90 \mathrm{~mm}$ deep studs and track, Yu \& Chen [13] demonstrated that the nominal shear resistance values obtained for walls of standard construction can also be used for the design of shear walls configured with framing members of $152 \mathrm{~mm}$ deep assuming the steel is of the same thickness and grade.

Short length walls $(610 \times 2440 \mathrm{~mm})$ were excluded from the database used to determine the tabulated nominal shear resistance values, but were considered in a verification of the AISI S213 [1] shear resistance reduction factor $2 \mathrm{w} / \mathrm{h}$ requirement for high aspect ratio walls, i.e. for walls with aspect ratio $\mathrm{h} / \mathrm{w}(\mathrm{h}=$ height $\& \mathrm{w}=$ length) greater than 2:1 but not exceeding 4:1. The shear resistance $\mathrm{S}_{\mathrm{y}}$ of the short length walls calibrated for thickness and tensile strength resulted in higher values than the nominal shear resistance as listed in Table 4 modified with the $2 \mathrm{w} / \mathrm{h}$ factor. Also, the drifts and shear resistances of nominally identical short and standard length walls were compared. It was determined that at the lateral displacement the tested short length 
walls attained the reduced nominal resistance level $2 \mathrm{w} / \mathrm{h} \times \mathrm{S}_{\mathrm{y}}$, similar drifts to the standard walls were reached. Hence, the design values in Table 4 can be used for the shorter length walls if the existing AISI S213 reduction factor of $2 \mathrm{w} / \mathrm{h}$ for high aspect ratio shear walls is applied.

\subsection{Calibration of resistance factor}

Ultimate limit states design as per the National Building Code of Canada [23] requires the use of a factored resistance which must be greater than the combined factored loads for a particular load case, i.e. $\phi \mathrm{R} \geq \Sigma \alpha \mathrm{S}$. Where, $\phi$ is the resistance factor, $\mathrm{R}$ is the nominal resistance of structural member or assembly (the $\mathrm{S}_{\mathrm{y}}$ values listed in Table 4 in this case), $\alpha$ is the load factor and $\mathrm{S}$ is the effect of the particular specified load combination. A resistance factor was determined for the design of the steel sheathed shear walls using a method specified in CSA S136 [25]. The same method was implemented for the determination of the $\phi$ factor, based on the static wind loading scenario, found in AISI S213 [1] for wood sheathed CFS framed shear walls [4]. It is reliant on a calibration equation, Eq. 1, which originated from Ravindra \& Galambos [26], and is presented in a similar format in CSA S408 [27].

$\phi=C_{\phi}\left(M_{m} F_{m} P_{m}\right) e^{\left(-\beta_{o} \sqrt{V_{M}^{2}+V_{F}^{2}+C_{P} V_{P}^{2}+V_{S}^{2}}\right)}$

where, $\beta_{0}=$ reliability/safety index, $C_{\phi}=$ calibration coefficient, $C_{P}=$ correction factor for sample size $=(1+1 / n) m /(m-2)$ for $n \geq 4$, and 5.7 for $n=3, F_{m}=$ mean value of fabrication factor for type of component involved, $m=$ degree of freedom $=n-1, M_{m}=$ mean value of material factor for type of component involved, $\mathrm{n}=$ number of tests, $\mathrm{P}_{\mathrm{m}}=$ mean value of professional factor for tested component, $V_{\mathrm{F}}=$ coefficient of variation of fabrication factor, $\mathrm{V}_{\mathrm{m}}=$ coefficient 
of variation of material factor, $\mathrm{V}_{\mathrm{P}}=$ coefficient of variation of professional factor and $\mathrm{V}_{\mathrm{S}}=$ coefficient of variation of the load effect.

The target reliability index, $\beta_{0}$, describes the acceptable probability of failure; a value of 2.5 for structural members is listed by CSA S136 [25]. Given that the ultimate shear resistance exceeds the nominal shear resistance as obtained from the EEEP method, i.e. the shear walls exhibit overstrength, a higher $\beta_{0}$ was not considered necessary. The calibration coefficient, $\mathrm{C}_{\phi}=1.842$, was consistent with that determined by Branston et al. [4] based on wind load factor of $\alpha=1.4$ and a mean-to-nominal ratio of the wind load equal to 0.76 as per Bartlett et al. [28]. Note, the corresponding coefficient of variation for the wind loading for use in Eq. 1 is $V_{s}=0.37$.

The mean value of the professional factor, $\mathrm{P}_{\mathrm{m}}$, was calculated from Eq. 2; it is a function of the nominal shear wall resistance, $S_{y}$, as determined for each test specimen, the average shear wall resistance for a particular configuration, $\mathrm{S}_{\mathrm{y}, \mathrm{avg}}$, which is listed as $\mathrm{S}_{\mathrm{y}}$ in Table 4 , and the sample size of each configuration, $\mathrm{n}$. The coefficient of variation of the professional factor, $\mathrm{P}_{\mathrm{m}}$, was defined as $\mathrm{V}_{\mathrm{P}}$.

$\mathrm{P}_{\mathrm{m}}=\frac{\sum_{\mathrm{i}=1}^{\mathrm{n}}\left(\mathrm{S}_{\left.\mathrm{y} / \mathrm{S}_{\mathrm{y}, \mathrm{avg}}\right)}\right.}{\mathrm{n}}$

The mean values and corresponding coefficients of variation for the material factors (Table 5), $\mathrm{M}_{\mathrm{m}}$ and $\mathrm{V}_{\mathrm{M}}$, and the fabrication factors, $\mathrm{F}_{\mathrm{m}}$ and $\mathrm{V}_{\mathrm{F}}$, were obtained from CSA S136 [25] as defined for four relevant failure modes as per the observed behaviour of the test specimens. Only the screw connection failure modes, type 1 and type 2, were considered by DaBreo \& Rogers [9] since the remaining component failures modes, which are framing failures, were 
deemed eliminated by the quarter-point blocking reinforcement of the frame and the capacitybased method used for design of these second phase test walls.

A summary of the calculated resistance factor for each type of component failure and the average value obtained for the different phases of the testing programs are listed in Table 6. A resistance factor of 0.70 is recommended for ordinary steel sheathed shear walls and walls with blocking reinforcements that are to be designed to carry lateral wind loads. This value is marginally less than that determined through the calibration process; however, it is consistent with that used in the design of wood sheathed CFS framed shear walls. It is also recommended that $\phi=0.70$ be used in the seismic design of steel sheathed CFS framed shear walls. This recommendation is warranted because the resistance factor in seismic design is used in both the calculation of the equivalent static earthquake base shear, where the over-strength related seismic force modification factor $\mathrm{R}_{0}$ is a function of $\phi$ (see Section 3.6), and for the calculation of the factored shear resistance of a wall. In effect, since the $\phi$ factor is found on both the loading and resistance sides of the base ultimate limits states design equation a separate value for seismic design is not needed as long as $\phi=0.70$ is used in the determination of $R_{0}$.

\subsection{Factor of safety}

Although a factor of safety is not explicitly used in limit states design, values were determined for the purpose of providing a comparison with the historical value of 2.5 that is still used in standards that permit allowable strength design. The ratio of the measured ultimate shear resistance, $\mathrm{S}_{\mathrm{u}}$, of each individual shear wall specimen was compared with the factored resistance,

$\phi \times \mathrm{S}_{\mathrm{y}}$ (Table 4), for the relevant wall configuration (Fig. 8). Factors of safety, $\mathrm{S}_{\mathrm{u}} / \phi \mathrm{S}_{\mathrm{y}}$, were 
calculated for both the monotonic and reserved cyclic tests, for which an average $S_{u}$ value of the positive and negative cycles was used (Table 7). The average limit states design related safety factor for the combined monotonic and reversed cyclic data for the different testing programs ranges from 1.90 to 2.00. Furthermore, an equivalent allowable strength design factor of safety for the wind loading condition was provided (Table 8). The calculation of a factor of safety in this fashion allows for an understanding of the over-strength in comparison with the specified load level. The allowable strength design factor of safety was determined by incorporating the 2010 NBCC [23] load factor for wind loads, i.e. $1.4 \mathrm{~S}_{\mathrm{u}} / \phi \mathrm{S}_{\mathrm{y}}$. The average allowable strength design related safety factor for the combined monotonic and reversed cyclic data for the different testing programs ranges from 2.67 to 2.80 , above the 2.5 commonly used for allowable strength design of shear walls. These factors of safety apply to the case of lateral loading alone, except for the DaBreo \& Rogers [9] results, for which the shear walls were subjected to combined lateral and gravity loading.

\subsection{Capacity based design}

Earthquake-resistant design for building structures in Canada requires that the seismic force resisting system (SFRS) be designed following capacity based principles [1, 23], unless the seismic force modification factors used in the calculation of lateral loads are sufficiently low, e.g. $\mathrm{R}_{\mathrm{d}} \mathrm{R}_{0}<2.0$ for wood sheathed CFS framed shear walls. In the case of steel sheathed CFS framed shear walls, the sheathing screw connections represent the fuse element of the SFRS through which seismic energy is dissipated by the inelastic bearing deformations of the steel sheathing and tilting of the fasteners. The other elements of the SFRS are designed to resist the

probable capacity of the shear wall as controlled by the fuse element, and thereby remain 
essentially undamaged to preserve the ability of the structure to carry gravity loads postearthquake and to avoid collapse. The intent is to design CFS framed structures to meet the "Life Safety” level of performance. In the situation where for design $R_{d} R_{0}>2.0$ the shear wall is expected to enter into the inelastic range of behaviour and to reach its ultimate resistance during a design level seismic event, which according to the NBCC has a return period of 2475 years. Hence, an over-strength factor is used to estimate the probable capacity of the shear wall such that chord studs, track, collector elements, etc., can be designed. The over-strength factor is determined through a comparison of the measured ultimate shear resistance, $\mathrm{S}_{\mathrm{u}}$, of each test wall and the nominal shear resistance, $S_{y}$, specified for the related wall configuration (Table 4), i.e. the ratio of $S_{u} / S_{y}$, which is conceptually illustrated in Fig. 9.

The importance of using a capacity based design procedure is highlighted by the failure of the chord studs of double-storey shear wall ST2-b1 by out of plane-bending in the test program by Shamim et al. [11]. The studs in this case had not been designed by a proper capacity based procedure, and as a result failed under ground motion excitation, which resulted in a near collapse of the storey. Subsequent redesign of the wall in which a capacity design approach, as described by DaBreo et al. [10], was used for the selection of the chord stud and other members in the SFRS allowed for the successful testing of the replacement wall ST2-b2. The capacity design procedure ensures that the members in the SFRS have adequate resistance to withstand the imposed forces due to the combined seismic and gravity loads. To carry out this procedure an engineer requires the tabulated nominal shear resistance values (Table 4), as well as a defined over-strength in order to determine the ultimate resistance of the wall. The resulting overstrength values are listed for the different phases of the testing programs in Table 9. Based on 
these results a conservative global over-strength factor of 1.4 is recommended for used with steel sheathed CFS framed shear walls.

\subsection{Seismic force modification factors}

Using the equivalent static force procedure specified in the NBCC [23] to calculate the seismic base shear, V (Eq. 3), requires the specification of the seismic force modification factors, $R_{d}$ and $\mathrm{R}_{0}$.

$$
\mathrm{V}=\frac{\mathrm{S}\left(\mathrm{T}_{\mathrm{a}}\right) \mathrm{M}_{\mathrm{V}} \mathrm{I}_{\mathrm{e}} \mathrm{W}}{\mathrm{R}_{\mathrm{d}} \mathrm{R}_{\mathrm{O}}}
$$

Where $S\left(T_{a}\right)$ is the design spectral acceleration for the fundamental lateral period of vibration of the building, $T_{a} ; M_{v}$ is the factor accounting for higher mode effects; $I_{e}$ is the earthquake importance factor of the structure; $\mathrm{W}$ is the seismic weight of the structure (dead load plus $25 \%$ snow load); $R_{d}$ is the ductility-related seismic force modification factor and $R_{0}$ is the overstrength-related seismic force modification factor.

The ductility-related force modification factor is a measure of the fuse element's ability to dissipate energy through inelastic deformations. The $\mathrm{R}_{\mathrm{d}}$ factor was determined using Newmark’s \& Hall's [29] expression $R_{d}=\sqrt{2 \mu-1}$, for $0.1 s<T_{a}<0.5$ s. This expression relates the $R_{d}$ factor to the ductility ratio, $\mu$, obtained directly from the test results. Boudreault et al. [24] suggested that the expected natural period vibration of most light-framed structures should be between 0.3 and 0.5 seconds, and as such this equation was previously used by Branston et al. [4] to define $R_{d}$ for wood sheathed CFS framed shear walls.

The over-strength-related force modification factor is a measure of the reserve strength within the fuse element, which is calculated using a formula proposed by Mitchell et al. [30], in which 
$R_{0}=R_{\text {size }} R_{\phi} R_{\text {yield }} R_{\text {sh }} R_{\text {mech. }}$. The force modification factor is a function of: $R_{\text {size, addresses the }}$ over-strength due to a restricted choices or limitations of the sizes of components available to the designer; $\mathrm{R}_{\phi}=1 / \phi$, accounts for the over-strength due to the difference between nominal and factored resistances; $R_{\text {yield, }}$ the ratio of probable shear strength to nominal resistance (Table 9); $\mathrm{R}_{\text {sh, }}$ incorporates the possibility of strain hardening under load, which was taken as unity because the shear walls did not exhibit this behaviour; and lastly, $\mathrm{R}_{\text {mech, }}$ relates the over-strength developed when a collapse mechanism is formed, which was also taken as unity since the influence of a collapse mechanism has not yet been established for this type of system.

Since $R_{d}$ and $R_{0}$ were determined directly from the results of the shear wall test programs, for the purpose of this paper, they are referred to as 'test-based' factors (Tables $10 \& 11$ ). Interim values of $R_{d}=2.5$ and $R_{0}=1.7$, consistent with the values listed in the NBCC for wood sheathed CFS framed shear walls, are suggested. However, these values are not recommended for design until further verification has been completed by means of non-linear time history dynamic analyses of representative shear wall models [31] and building models [32] following an approach adopted from FEMA P695 [33], for example, on the quantification of building seismic performance factors. The purpose this approach is to develop fragility curves that are used to identify the probability of failure associated with the proposed design method, and specifically the seismic force modification R-values.

\section{Conclusions}

The information presented herein addresses the need for improved design provisions for steel sheathed CFS framed shear walls in the North American AISI S240 and S400 standards. Using a 
database of monotonic and reversed cyclic shear wall tests from research programs in Canada and the US nominal shear resistance values, $\mathrm{S}_{\mathrm{y}}$, for un-blocked and blocked walls were determined using the equivalent energy elastic-plastic (EEEP) method. This analysis method was used to produce a simplified bilinear elastic-plastic force-displacement curve for each test wall from which key design information was extracted. A resistance factor, $\phi=0.7$ is recommended along with an over-strength factor of 1.4 for capacity based seismic design calculations. For information purposes the associated factors of safety were provided for both a limit states and an allowable strength design approach. Test-based seismic force modification factors were also determined; interim values of $R_{d}=2.5$ and $R_{0}=1.7$ are suggested. However, verification of this test information is required following an approach through which the probability of failure for the design method, and specifically the R-values, can be established. This verification procedure is currently ongoing through the use of numerical non-linear time-history dynamic modeling of representative cold-formed steel framed buildings located in various seismic zones following the FEMA P695 methodology for the evaluation of building seismic performance.

\section{Acknowledgements}

The authors would like to thank the Natural Sciences and Engineering Research Council of Canada (NSERC), the Canadian Sheet Steel Building Institute (CSSBI) and the American Iron and Steel Institute (AISI) for the financial support of the research described herein. Materials for construction of the test specimens were provided by Simpson Strong-Tie Co. Inc., ITW Buildex and Grabber Construction Products. Assistance with the procurement of steel framing was provided by Bailey Metal Products Limited. 


\section{References}

[1] American Iron and Steel Institute (AISI). North American standard for cold-formed steel framing - lateral design. AISI S213. Washington, USA; 2007.

[2] American Iron and Steel Institute (AISI). North American standard for cold-formed steel structural framing. AISI S240. Washington, USA; 2014.

[3] American Iron and Steel Institute (AISI). North American standard for seismic design of cold-formed steel structural systems. AISI S400. Washington, USA; 2014.

[4] Branston AE, Boudreault FA, Chen CY, Rogers CA. Light-gauge steel-frame - wood structural panel shear wall design method. Canadian Journal of Civil Engineering 2006; 33(7): 872-89.

[5] Branston AE, Chen CY, Boudreault FA, Rogers CA. Testing of light-gauge steel-frame wood structural panel shear walls. Canadian Journal of Civil Engineering 2006; 33(5): 561-572.

[6] Chen CY, Boudreault FA, Branston AE, Rogers CA. Behaviour of light-gauge steel-frame wood structural panel shear walls. Canadian Journal of Civil Engineering 2006; 33(5): 573-587.

[7] Ong-Tone C, Rogers CA. Tests and evaluation of cold-formed steel frame /steel sheathed shear walls, Research Report. Montreal, Canada: Dept. of Civil Engineering \& Applied Mechanics, McGill University; 2009.

[8] Balh N, Rogers CA. Development of seismic design provisions for steel sheathed shear walls, Research Report. Montreal, Canada: Dept. of Civil Engineering \& Applied Mechanics, McGill University; 2010.

[9] DaBreo J, Rogers CA. Steel sheathed shear walls subjected to combined lateral and gravity loads, Research Report. Montreal, Canada: Dept. of Civil Engineering \& Applied Mechanics, McGill University; 2012.

[10] DaBreo J, Balh N, Ong-Tone C, Rogers CA. Steel sheathed - cold-formed steel framed shear walls subjected to lateral and gravity loading. Thin-Walled Structures, in press TWST 4093.

[11] Shamim I, DaBreo J, Rogers CA. Dynamic testing of single- and double-story steel sheathed cold-formed steel framed shear walls. Journal of Structural Engineering ASCE 2013; 139(5): 807-817. 
[12] Yu C, Vora H, Dainard T, Tucker J, Veetvkuri P. Steel sheet sheathing options for coldformed steel framed shear wall assemblies providing shear resistance, Report No. UNTG76234. Denton, USA; Dept. of Engineering Technology, University of North Texas; 2007.

[13] Yu C, Chen Y. Steel sheet sheathing options for cold-formed steel framed shear wall assemblies providing shear resistance - Phase 2, Report No. UNT-G70752. Denton, USA; Dept. of Engineering Technology, University of North Texas; 2009.

[14] Ellis J. Shear resistance of cold-formed steel framed shear wall assemblies using CUREE test protocol. Simpson Strong-Tie Co. Inc, Anaheim, USA; 2007.

[15] Park R. Evaluation of ductility of structures and structural assemblages from laboratory testing. Bulletin of the New Zealand National Society for Earthquake Engineering 1989; 22(3): 155-166.

[16] Foliente GC. Issues in seismic performance testing and evaluation of timber structural systems. Proc. International Wood Engineering Conference. New Orleans, LA, 1996; 1: 29-36.

[17] American Society for Testing and Materials (ASTM). Standard test methods for cyclic (reversed) load test for shear resistance of vertical elements of the lateral force resisting systems for buildings. ASTM E2126. West Conshohocken, USA; 2011.

[18] El-Saloussy K, Rogers CA. Additional cold-formed steel frame / steel sheathed shear wall design values for Canada. Research Report. Montreal, Canada: Dept. of Civil Engineering \& Applied Mechanics, McGill University; 2010.

[19] Krawinkler H, Parisi F, Ibarra L, Ayoub A, Medina, R. Development of a testing protocol for woodframe structures. Report W-02 covering Task 1.3.2, CUREE/Caltech Woodframe Project. Consortium of Universities for Research in Earthquake Engineering (CUREE). Richmond, USA; 2000.

[20] American Iron and Steel Institute (AISI). Standard for cold-formed steel framing prescriptive method for one and two family dwellings. AISI S230. Washington, USA; 2007.

[21] American Society for Testing and Materials (ASTM). Standard specification for steel sheet, zinc-coated (galvanized) or zinc-iron alloy-coated (galvannealed) by hot-dip prcess. ASTM A653, West Conshohocken, USA. 2008.

[22] American Society for Testing and Materials (ASTM). Standard specification for steel sheet, carbon, metallic- and nonmetallic-coated for cold-formed framing members. ASTM A1003, West Conshohocken, USA. 2005. 
[23] National Research Council of Canada (NRCC). National Building Code of Canada. $13^{\text {th }}$ Edition. Ottawa, Canada. 2010.

[24] Boudreault FA, Blais C, Rogers CA. Seismic force modification factors for light-gauge steel-frame - wood structural panel shear walls. Canadian Journal of Civil Engineering 2007; 34(1): 56-65.

[25] Canadian Standards Association (CSA). North American specification for the design of cold-formed steel structural members. CSA S136. Mississauga, Canada. 2007.

[26] Ravindra MK, Galambos TV. Load and resistance factor design for steel. Journal of the Structural Division ASCE 1978; 104(ST9): 1337-1353.

[27] Canadian Standards Association (CSA). Guidelines for the development of limit states design. CSA S408. Mississauga, Canada. 1981.

[28] Bartlett FM, Hong HP, Zhou W. Load factor calibration for the proposed 2005 edition of the National Building Code of Canada: Statistics of loads and load effects. Canadian Journal of Civil Engineering 2003; 30(2): 429 - 439.

[29] Newmark NM, Hall WJ. Earthquake spectra and design. Engineering Monograph, Earthquake Engineering Research Institute, Berkeley, USA. 1982.

[30] Mitchell D, Tremblay R, Karacabeyli E, Paultre P, Saatcioglu M, Anderson DL. Seismic force modification factors for the proposed 2005 edition of the National Building Code of Canada. Canadian Journal of Civil Engineering 2003; 30(2): 308-327.

[31] Shamim, I, Rogers, CA. Steel sheathed - CFS framed shear walls under dynamic loading: numerical modelling and calibration. Thin-Walled Structures 2013; 71: 57-71.

[32] Shamim, I. Seismic design of lateral force resisting cold-formed steel framed (CFS) structures. $\mathrm{PhD}$ thesis. Montreal, Canada: Department of Civil Engineering \& Applied Mechanics, McGill University; 2013.

[33] Federal Emergency Management Agency (FEMA). Quantification of building seismic performance factors. FEMA P695. Washington, USA. 2009. 
Table 1: Matrix of shear wall test configurations from McGill University studies [7-10]

\begin{tabular}{|c|c|c|c|c|c|c|}
\hline Configuration & $\begin{array}{c}\text { Number of } \\
\text { Tests \& } \\
\text { Protocol }^{4}\end{array}$ & $\begin{array}{l}\text { Wall } \\
\text { Length } \\
(\mathrm{mm})\end{array}$ & $\begin{array}{c}\text { Wall Height } \\
(\mathrm{mm})\end{array}$ & $\begin{array}{c}\text { Framing } \\
\text { Thickness } \\
\text { (mm) }\end{array}$ & $\begin{array}{l}\text { Sheathing } \\
\text { Thickness } \\
\text { (mm) }\end{array}$ & $\begin{array}{c}\text { Fastener }^{5} \\
\text { Schedule } \\
(\mathrm{mm})\end{array}$ \\
\hline $1^{1}$ & $3 \mathrm{M} \& 2 \mathrm{C}$ & 1220 & 2440 & 1.09 & 0.46 & $150 / 300$ \\
\hline $2^{1}$ & $2 \mathrm{M} \& 2 \mathrm{C}$ & 1220 & 2440 & 1.09 & 0.46 & 50/300 \\
\hline $3^{1}$ & $2 \mathrm{M} \& 3 \mathrm{C}$ & 1220 & 2440 & 0.84 & 0.46 & $150 / 300$ \\
\hline $4^{2}$ & $2 \mathrm{M} \& 2 \mathrm{C}$ & 1220 & 2440 & 1.09 & 0.76 & $150 / 300$ \\
\hline $5^{2}$ & $2 \mathrm{M} \& 2 \mathrm{C}$ & 1220 & 2440 & 1.09 & 0.76 & $100 / 300$ \\
\hline $6^{2}$ & $2 \mathrm{M} \& 2 \mathrm{C}$ & 1220 & 2440 & 1.09 & 0.76 & 50/300 \\
\hline $8^{1}$ & $2 \mathrm{M} \& 2 \mathrm{C}$ & 610 & 2440 & 1.09 & 0.76 & 100 \\
\hline $9^{1}$ & $2 \mathrm{M} \& 2 \mathrm{C}$ & 610 & 2440 & 1.09 & 0.76 & 50 \\
\hline $11^{1}$ & $2 \mathrm{M} \& 2 \mathrm{C}$ & 2440 & 2440 & 1.09 & 0.76 & 100/300 \\
\hline $12^{2}$ & $1 \mathrm{M}$ & 1830 & 2440 & 1.09 & 0.76 & $100 / 300$ \\
\hline $13^{2}$ & $1 \mathrm{M}$ & 1830 & 2440 & 1.09 & 0.76 & 50/300 \\
\hline $\mathrm{B} 1^{3}$ & $1 \mathrm{M} \& 1 \mathrm{R}$ & 1220 & 2440 & 1.37 & 0.76 & 50/300 \\
\hline $\mathrm{B}^{3}{ }^{3}$ & $1 \mathrm{M} \& 1 \mathrm{R}$ & 1220 & 2440 & 1.09 & 0.46 & 50/300 \\
\hline $\mathrm{B}^{3}$ & $1 \mathrm{M} \& 1 \mathrm{R}$ & 1220 & 2440 & 1.09 & 0.76 & $100 / 300$ \\
\hline $\mathrm{B} 4^{3}$ & $1 \mathrm{M} \& 1 \mathrm{R}$ & 1220 & 2440 & 1.09 & 0.76 & $150 / 300$ \\
\hline $\mathrm{B} 5^{3}$ & $1 \mathrm{M} \& 1 \mathrm{R}$ & 1220 & 2440 & 1.09 & 0.46 & $100 / 300$ \\
\hline$B 6^{3}$ & $1 \mathrm{M} \& 1 \mathrm{R}$ & 1220 & 2440 & 1.09 & 0.46 & 150/300 \\
\hline $\mathrm{B} 7^{3}$ & $1 \mathrm{M}$ & 1220 & 2440 & 1.37 & 0.76 & 75/300 \\
\hline $\mathrm{B}^{3}$ & $1 \mathrm{M}$ & 1220 & 2440 & 1.37 & 0.46 & 75/300 \\
\hline
\end{tabular}

${ }^{1}$ Balh \& Rogers [8]

${ }^{2}$ Ong-Tone \& Rogers [7]

${ }^{3}$ DaBreo \& Rogers [9]; frames reinforced with quarter-point blocking (same size as track members).

${ }^{4}$ M-Monotonic, C/R-CUREE reserved cyclic protocol for ordinary ground motions [17,19].

${ }^{5}$ Fastener schedule (e.g. 75/300) refers to the approx. spacing in mm between the sheathing to framing screws on the panel perimeter and along the intermediate studs (field spacing), respectively. 
Table 2: Matrix of shear wall test configurations from the University of North Texas studies $[12,13]$

\begin{tabular}{|c|c|c|c|c|c|c|}
\hline Configuration & $\begin{array}{c}\text { Number of } \\
\text { Tests \& } \\
\text { Protocol }^{3}\end{array}$ & $\begin{array}{c}\text { Wall } \\
\text { Length } \\
\text { (mm) }\end{array}$ & $\begin{array}{c}\text { Wall } \\
\text { Height } \\
(\mathrm{mm})\end{array}$ & $\begin{array}{c}\text { Framing } \\
\text { Thickness } \\
\text { (mm) }\end{array}$ & $\begin{array}{c}\text { Sheathing } \\
\text { Thickness } \\
(\mathrm{mm})\end{array}$ & $\begin{array}{c}\text { Fastener }^{4} \\
\text { Schedule } \\
(\mathrm{mm})\end{array}$ \\
\hline \multicolumn{7}{|l|}{ Phase $1^{1}$} \\
\hline $4 \times 8 \times 43 \times 33-6 / 12$ & $2 \mathrm{M} \& 2 \mathrm{C}$ & 1220 & 2440 & 1.09 & 0.84 & $150 / 300$ \\
\hline $4 \times 8 \times 43 \times 33-4 / 12$ & $2 \mathrm{M} \& 2 \mathrm{C}$ & 1220 & 2440 & 1.09 & 0.84 & $100 / 300$ \\
\hline $4 \times 8 \times 43 \times 33-2 / 12$ & $2 \mathrm{M} \& 2 \mathrm{C}$ & 1220 & 2440 & 1.09 & 0.84 & $50 / 300$ \\
\hline $4 \times 8 \times 43 \times 30-6 / 12$ & $2 \mathrm{M} \& 2 \mathrm{C}$ & 1220 & 2440 & 1.09 & 0.76 & $150 / 300$ \\
\hline $4 \times 8 \times 43 \times 30-4 / 12$ & $2 \mathrm{M} \& 1 \mathrm{C}$ & 1220 & 2440 & 1.09 & 0.76 & $100 / 300$ \\
\hline $4 \times 8 \times 43 \times 30-2 / 12$ & $2 \mathrm{M} \& 1 \mathrm{C}$ & 1220 & 2440 & 1.09 & 0.76 & $50 / 300$ \\
\hline $4 \times 8 \times 33 \times 27-6 / 12$ & $2 \mathrm{M} \& 2 \mathrm{C}$ & 1220 & 2440 & 0.84 & 0.68 & $150 / 300$ \\
\hline $4 \times 8 \times 33 \times 27-4 / 12$ & $2 \mathrm{M} \& 2 \mathrm{C}$ & 1220 & 2440 & 0.84 & 0.68 & $100 / 300$ \\
\hline $4 \times 8 \times 33 \times 27-2 / 12$ & $2 \mathrm{M} \& 2 \mathrm{C}$ & 1220 & 2440 & 0.84 & 0.68 & $50 / 300$ \\
\hline $2 \times 8 \times 43 \times 33-6$ & $2 \mathrm{M} \& 2 \mathrm{C}$ & 610 & 2440 & 1.09 & 0.84 & 150 \\
\hline $2 \times 8 \times 43 \times 33-4$ & $2 \mathrm{M} \& 2 \mathrm{C}$ & 610 & 2440 & 1.09 & 0.84 & 100 \\
\hline $2 \times 8 \times 43 \times 33-2$ & $2 \mathrm{M} \& 2 \mathrm{C}$ & 610 & 2440 & 1.09 & 0.84 & 50 \\
\hline $2 \times 8 \times 43 \times 30-6$ & $2 \mathrm{M} \& 2 \mathrm{C}$ & 610 & 2440 & 1.09 & 0.76 & 150 \\
\hline $2 \times 8 \times 43 \times 30-4$ & $2 \mathrm{M} \& 2 \mathrm{C}$ & 610 & 2440 & 1.09 & 0.76 & 100 \\
\hline $2 \times 8 \times 43 \times 30-2$ & $2 \mathrm{M} \& 2 \mathrm{C}$ & 610 & 2440 & 1.09 & 0.76 & 50 \\
\hline \multicolumn{7}{|l|}{ Phase $2^{2}$} \\
\hline $8 \times 2 \times 350-33 \times 27-6$ & $2 \mathrm{M} \& 2 \mathrm{C}$ & 610 & 2440 & 0.84 & 0.68 & 150 \\
\hline $8 \times 4 \times 350-33 \times 18-6$ & $2 \mathrm{M} \& 2 \mathrm{C}$ & 1220 & 2440 & 0.84 & 0.46 & $150 / 300$ \\
\hline $8 \times 2 \times 350-33 \times 27-2$ & $2 \mathrm{M} \& 2 \mathrm{C}$ & 610 & 2440 & 0.84 & 0.68 & 50 \\
\hline $8 \times 6 \times 350-43 \times 33-2-C^{6}$ & $1 \mathrm{M} \& 2 \mathrm{C}$ & 1830 & 2440 & 1.09 & 0.84 & $50 / 300^{5}$ \\
\hline $8 \times 6 \times 350-43 \times 30-2-C^{6}$ & $1 \mathrm{M} \& 2 \mathrm{C}$ & 1830 & 2440 & 1.09 & 0.76 & $50 / 300^{5}$ \\
\hline $8 \times 6 \times 600-43 \times 33-2-C^{6}$ & $1 \mathrm{M} \& 2 \mathrm{C}$ & 1830 & 2440 & 1.09 & 0.84 & $50 / 300^{5}$ \\
\hline $8 \times 6 \times 350-54 \times 33-2-B$ & $1 \mathrm{M} \& 2 \mathrm{C}$ & 1830 & 2440 & 1.37 & 0.84 & $50 / 300$ \\
\hline $8 \times 6 \times 350-43 \times 27-2-D$ & $1 \mathrm{M} \& 1 \mathrm{C}$ & 1830 & 2440 & 1.09 & 0.68 & $50 / 300^{5}$ \\
\hline $8 \times 6 \times 350-54 \times 33-2-C^{6}$ & $1 \mathrm{M} \& 2 \mathrm{C}$ & 1830 & 2440 & 1.37 & 0.84 & $50 / 300^{5}$ \\
\hline $8 \times 6 \times 350-43 \times 30-2-A$ & $1 \mathrm{C}$ & 1830 & 2440 & 1.09 & 0.76 & $50 / 300$ \\
\hline $8 \times 6 \times 350-43 \times 30-2-B$ & 1C & 1830 & 2440 & 1.09 & 0.76 & $50 / 300$ \\
\hline $8 \times 4 \times 350-43 \times 33-2-C^{6}$ & $2 \mathrm{C}$ & 1220 & 2440 & 1.09 & 0.84 & $50 / 300^{5}$ \\
\hline $8 \times 2 \times 350-43 \times 33-2-C^{6}$ & $2 \mathrm{C}$ & 610 & 2440 & 1.09 & 0.84 & $50^{5}$ \\
\hline
\end{tabular}

${ }^{1}$ Yu et al. [12]

${ }^{2} \mathrm{Yu} \&$ Chen [13]

${ }^{3}$ M-Monotonic, C-CUREE reserved cyclic protocol for ordinary ground motions [17,19].

${ }^{4}$ Fastener schedule (e.g. 75/300) refers to the approx. spacing in mm between the sheathing to framing screws on the panel perimeter and along the intermediate studs (field spacing), respectively.

${ }^{5}$ No. 10x19.1mm self-drilling / self-tapping screws used

${ }^{6}$ Mid-height blocking used in accordance with strapping and blocking detail - Section E AISI S230 detail [20]. 
Table 3: Comparison of nominal shear resistance values, $S_{y}$, of standard walls and mid-height blocked walls

\begin{tabular}{cccc}
\hline $\begin{array}{c}\text { Assembly } \\
\text { description }\end{array}$ & $\begin{array}{c}\text { Aspect ratio } \\
(\mathrm{h} / \mathrm{w})\end{array}$ & $\begin{array}{c}\text { Nominal shear resistance } \\
(\mathrm{kN} / \mathrm{m})\end{array}$ & $\begin{array}{c}\text { Mid-height } \\
\text { blocking }\end{array}$ \\
\hline $\begin{array}{c}0.84 \mathrm{~mm} \\
\text { sheathing } \\
\&\end{array}$ & $2: 1$ & 13.95 & No \\
$\begin{array}{c}50 \text { mm fastener } \\
\text { spacing }\end{array}$ & $4: 3$ & 14.67 & Yes \\
& $4: 3$ & 18.15 & No \\
\hline
\end{tabular}


Table 4: Proposed nominal shear resistance, $\mathrm{S}_{\mathrm{y}}(\mathrm{kN} / \mathrm{m})$, for steel sheathed CFS framed shear walls $s^{1,2,3}$

\begin{tabular}{cccccccccc}
\hline $\begin{array}{c}\text { Sheathing } \\
\text { thicknes } \\
(\mathrm{mm})\end{array}$ & $\begin{array}{c}\text { Max. } \\
\text { Aspect } \\
\text { Ratio } \\
(\mathrm{h} / \mathrm{w})^{4,5}\end{array}$ & \multicolumn{3}{c}{$\begin{array}{c}\text { Fastener Spacing }{ }^{6} \text { at Panel Edges } \\
(\mathrm{mm})\end{array}$} & & $\begin{array}{c}\text { Frame } \\
\text { Blocking }\end{array}$ & $\begin{array}{c}\text { Thickness }{ }^{7} \text { of } \\
\text { Stud, Track, } \\
\text { and Blocking } \\
(\mathrm{mm})\end{array}$ & $\begin{array}{c}\text { Sheathing } \\
\text { Screw Size }\end{array}$ \\
\hline 0.46 & $2: 1$ & 4.1 & - & - & - & No & 0.84 & 8 \\
0.46 & $2: 1$ & 4.5 & 6.0 & 6.8 & 7.5 & No & 1.09 & 8 \\
0.68 & $2: 1$ & 6.5 & 7.2 & 7.9 & 8.7 & No & 0.84 & 8 \\
0.76 & $4: 1$ & 8.9 & 10.6 & 11.6 & 12.5 & No & 1.09 & 8 \\
0.84 & $4: 1$ & 10.7 & 12.0 & 13.0 & 14.0 & No & 1.09 & 8 \\
\hline 0.46 & $2: 1$ & 7.4 & 9.7 & 11.6 & 13.5 & Quarter-point & 1.09 & 8 \\
0.76 & $2: 1$ & 11.7 & 14.3 & - & - & Quarter-point & 1.09 & 8 \\
0.76 & $2: 1$ & - & - & 19.9 & 23.3 & Quarter-point & 1.37 & 8 \\
\hline
\end{tabular}

${ }^{1}$ Nominal shear resistance, $S_{y}$, to be multiplied by resistance factor, $\phi=0.7$.

${ }^{2}$ Nominal shear resistance values for walls with steel sheathing on one side.

${ }^{3}$ Sheathing panels to be connected vertically to the steel frame.

${ }^{4}$ Nominal resistances are to be multiplied by $2 \mathrm{w} / \mathrm{h}$ for aspect ratios greater than 2:1 but no greater than 4:1.

${ }^{5}$ For walls that require multiple vertical sheathing panels, a single stud is to be used at the sheathing joint.

${ }^{6}$ Edge screws installed at least $9.5 \mathrm{~mm}$ from the sheathing edge and field screws to be spaced $300 \mathrm{~mm}$ o-c.

${ }^{7}$ Steel with $\mathrm{t} \leq 1.09 \mathrm{~mm}$ use ASTM A653 grade $230 \mathrm{MPa}$ or equivalent. Steel with $\mathrm{t} \geq 1.37 \mathrm{~mm}$ use ASTM A653 grade $340 \mathrm{MPa}$ or equivalent. 
Table 5: Statistical data for the determination of resistance factor [25]

\begin{tabular}{|c|c|c|c|c|}
\hline Type of Component and Failure Mode & $\mathrm{M}_{\mathrm{m}}$ & $\mathrm{V}_{\mathrm{M}}$ & $\mathrm{F}_{\mathrm{m}}$ & $\mathrm{V}_{\mathrm{F}}$ \\
\hline $\begin{array}{l}\text { Type 1: Connection- } \\
\text { Shear Strength of Screw }\end{array}$ & 1.10 & 0.10 & 1.00 & 0.10 \\
\hline $\begin{array}{l}\text { Type 2: Connection- } \\
\text { Bearing and Tilting Strength of Screw }\end{array}$ & 1.10 & 0.08 & 1.00 & 0.05 \\
\hline $\begin{array}{l}\text { Type 3: Wall Studs- } \\
\text { Chord stud in compression }\end{array}$ & 1.10 & 0.10 & 1.00 & 0.05 \\
\hline $\begin{array}{l}\text { Type 4: Structural Members not listed- } \\
\text { Uplift of Track }\end{array}$ & 1.00 & 0.10 & 1.00 & 0.05 \\
\hline
\end{tabular}


Table 6: Summary of resistance factor, $\phi$, calibration results for different types of component failure modes

\begin{tabular}{ccccc}
\hline Type of Component failure & $\begin{array}{c}\text { McGill Phase } \\
\text { 1a Tests }^{1}\end{array}$ & $\begin{array}{c}\text { McGill Phase } \\
\text { 1b Tests }\end{array}$ & $\begin{array}{c}\text { North Texas } \\
\text { Phase 1 \& 2 tests }^{3}\end{array}$ & $\begin{array}{c}\text { McGill Phase 2 } \\
\text { Tests }^{4}\end{array}$ \\
\hline Type 1 & 0.75 & 0.75 & 0.74 & 0.75 \\
Type 2 & 0.78 & 0.77 & 0.77 & 0.78 \\
Type 3 & 0.77 & 0.76 & 0.76 & - \\
Type 4 & 0.70 & 0.69 & 0.69 & - \\
Average & 0.75 & 0.74 & 0.74 & 0.77 \\
\hline
\end{tabular}

${ }^{1}$ Shear wall data from test program by Ong-Tone \& Rogers [7].

${ }^{2}$ Shear wall data from test program by Balh \& Rogers [8].

${ }^{3}$ Shear wall data from test programs by Yu et al. [12] \& Yu \& Chen [13]; analysed by El-Saloussy \& Rogers [18].

${ }^{4}$ Shear wall data from test program by DaBreo \& Rogers [9]. 
Table 7: Factor of safety values for limit states design

\begin{tabular}{|c|c|c|c|c|c|}
\hline \multicolumn{2}{|c|}{$\begin{array}{l}\text { Factor of Safety } \\
\qquad \mathrm{S}_{\mathrm{u}} / \phi \mathrm{S}_{\mathrm{y}}\end{array}$} & \multirow{2}{*}{$\begin{array}{c}\text { McGill Phase } \\
\text { 1a Tests }{ }^{1}\end{array}$} & \multirow{2}{*}{$\begin{array}{c}\begin{array}{c}\text { McGill } \\
\text { Phase 1b } \\
\text { Tests }^{2}\end{array} \\
1.97\end{array}$} & \multirow{2}{*}{$\begin{array}{c}\text { North Texas } \\
\text { Phase } 1 \& 2 \\
\text { tests }^{3} \\
1.92\end{array}$} & \multirow{2}{*}{$\begin{array}{c}\begin{array}{c}\text { McGill } \\
\text { Phase } 2 \\
\text { Tests }^{4}\end{array} \\
1.91\end{array}$} \\
\hline & Avg & & & & \\
\hline \multirow[t]{3}{*}{ Monotonic } & SD & 0.94 & 0.09 & 0.13 & 0.13 \\
\hline & $\mathrm{COV}$ & 0.008 & 0.007 & 0.017 & 0.016 \\
\hline & Avg & 1.93 & 2.03 & 2.04 & 1.91 \\
\hline \multirow[t]{2}{*}{ Reversed cyclic } & SD & 0.05 & 0.07 & 0.11 & 0.11 \\
\hline & $\mathrm{COV}$ & 0.002 & 0.005 & 0.012 & 0.013 \\
\hline Combined & Avg & 1.90 & 2.00 & 1.98 & 1.91 \\
\hline
\end{tabular}

${ }^{1}$ Shear wall data from test program by Ong-Tone \& Rogers [7].

${ }^{2}$ Shear wall data from test program by Balh \& Rogers [8].

${ }^{3}$ Shear wall data from test programs by Yu et al. [12] \& Yu \& Chen [13]; analysed by El-Saloussy \& Rogers [18].

${ }^{4}$ Shear wall data from test program by DaBreo \& Rogers [9]. 
Table 8: Factor of safety values for allowable strength design (wind loading)

\begin{tabular}{|c|c|c|c|c|c|}
\hline \multicolumn{2}{|c|}{$\begin{array}{c}\text { Factor of Safety } \\
1.4 \mathrm{~S}_{\mathrm{u}} / \phi \mathrm{S}_{\mathrm{y}}\end{array}$} & $\begin{array}{c}\text { McGill Phase } \\
\text { 1a Tests }{ }^{1}\end{array}$ & \multirow{2}{*}{$\begin{array}{c}\text { McGill } \\
\begin{array}{c}\text { Phase 1b } \\
\text { Tests }^{2}\end{array} \\
2.76\end{array}$} & \multirow{2}{*}{$\begin{array}{c}\text { North Texas } \\
\text { Phase } 1 \& 2 \\
\text { tests }^{3} \\
2.68\end{array}$} & \multirow{2}{*}{$\begin{array}{c}\begin{array}{c}\text { McGill } \\
\text { Phase } 2 \\
\text { Tests }\end{array} \\
2.68\end{array}$} \\
\hline \multirow{4}{*}{ Monotonic } & Avg & 2.62 & & & \\
\hline & SD & 0.12 & 0.12 & 0.19 & 0.18 \\
\hline & $\mathrm{COV}$ & 0.015 & 0.014 & 0.034 & 0.031 \\
\hline & Avg & 2.71 & 2.84 & 2.849 & 2.67 \\
\hline \multirow[t]{2}{*}{ Reversed cyclic } & SD & 0.07 & 0.10 & 0.15 & 0.16 \\
\hline & $\mathrm{COV}$ & 0.005 & 0.010 & 0.023 & 0.026 \\
\hline Combined & Avg & 2.67 & 2.80 & 2.70 & 2.68 \\
\hline
\end{tabular}

${ }^{1}$ Shear wall data from test program by Ong-Tone \& Rogers [7].

${ }^{2}$ Shear wall data from test program by Balh \& Rogers [8].

${ }^{3}$ Shear wall data from test programs by Yu et al. [12] \& Yu \& Chen [13]; analysed by El-Saloussy \& Rogers [18].

${ }^{4}$ Shear wall data from test program by DaBreo \& Rogers [9]. 
Table 9: Over-strength values for steel sheathed shear walls when nominal shear resistance obtained using the EEEP analysis approach

\begin{tabular}{|c|c|c|c|c|c|}
\hline \multicolumn{2}{|c|}{$\begin{array}{l}\text { Overstrength } \\
\mathrm{S}_{\mathrm{u}} / \mathrm{S}_{\mathrm{y}}\end{array}$} & $\begin{array}{l}\text { McGill Phase } \\
\text { 1a Tests }{ }^{1}\end{array}$ & \multirow{2}{*}{$\begin{array}{c}\begin{array}{c}\text { McGill } \\
\text { Phase 1b } \\
\text { Tests }^{2}\end{array} \\
1.38\end{array}$} & \multirow{2}{*}{$\begin{array}{c}\text { North Texas } \\
\text { Phase } 1 \& 2 \\
\text { tests }^{3}\end{array}$} & \multirow{2}{*}{$\begin{array}{r}\begin{array}{r}\text { McGill } \\
\text { Phase } 2 \\
\text { Tests }\end{array} \\
1.34\end{array}$} \\
\hline \multirow{3}{*}{ Monotonic } & Avg & 1.31 & & & \\
\hline & SD & 0.06 & 0.06 & 0.09 & 0.09 \\
\hline & $\mathrm{COV}$ & 0.004 & 0.004 & 0.009 & 0.008 \\
\hline \multirow{3}{*}{ Reversed cyclic } & Avg & 1.35 & 1.42 & 1.42 & 1.34 \\
\hline & SD & 0.03 & 0.05 & 0.08 & 0.08 \\
\hline & $\mathrm{COV}$ & 0.001 & 0.002 & 0.006 & 0.006 \\
\hline Combined & Avg & 1.33 & 1.40 & 1.38 & 1.34 \\
\hline
\end{tabular}

${ }^{1}$ Shear wall data from test program by Ong-Tone \& Rogers [7].

${ }^{2}$ Shear wall data from test program by Balh \& Rogers [8].

${ }^{3}$ Shear wall data from test programs by Yu et al. [12] \& Yu \& Chen [13]; analysed by El-Saloussy \& Rogers [18].

${ }^{4}$ Shear wall data from test program by DaBreo \& Rogers [9]. 
Table 10: Test-based $\mathrm{R}_{\mathrm{d}}$ values for steel sheathed CFS framed shear walls

\begin{tabular}{cccccc}
\hline \multirow{2}{*}{ Ductility related force modification factor, $\mathrm{R}_{\mathrm{d}}$} & $\begin{array}{c}\text { McGill Phase } \\
\text { a Tests }^{1}\end{array}$ & $\begin{array}{c}\text { McGill } \\
\text { Phase 1b }^{2} \\
\text { Tests }^{2}\end{array}$ & $\begin{array}{c}\text { North Texas } \\
\text { Phase 1 \& 2 }_{\text {tests }^{3}}\end{array}$ & $\begin{array}{c}\text { McGill } \\
\text { Phase 2 } \\
\text { Tests }^{4}\end{array}$ \\
\hline \multirow{3}{*}{ Monotonic } & Avg. & 4.23 & 2.93 & 2.36 & 3.02 \\
& SD & 0.37 & 0.90 & 0.47 & 0.55 \\
\cline { 2 - 6 } Reversed cyclic & COV & 0.134 & 0.804 & 0.221 & 0.301 \\
\hline \multirow{2}{*}{ Combined } & Avg. & 3.46 & 2.81 & 2.45 & 2.83 \\
& SD & 0.07 & 0.71 & 0.47 & 0.27 \\
\cline { 2 - 6 } & COV & 0.004 & 0.507 & 0.221 & 0.070 \\
\hline
\end{tabular}

${ }^{1}$ Shear wall data from test program by Ong-Tone \& Rogers [7].

${ }^{2}$ Shear wall data from test program by Balh \& Rogers [8].

${ }^{3}$ Shear wall data from test programs by Yu et al. [12] \& Yu \& Chen [13]; analysed by El-Saloussy \& Rogers [18].

${ }^{4}$ Shear wall data from test program by DaBreo \& Rogers [9]. 
Table 11: Test-based $\mathrm{R}_{0}$ values for steel sheathed CFS framed shear walls

\begin{tabular}{ccccc}
\hline $\begin{array}{c}\text { Over-strength related force } \\
\text { modification factor, } \mathrm{R}_{\mathrm{o}}\end{array}$ & $\begin{array}{c}\text { McGill } \\
\text { Phase 1a } \\
\text { Tests }^{1}\end{array}$ & $\begin{array}{c}\text { McGill } \\
\text { Phase 1b } \text { Tests }^{2}\end{array}$ & $\begin{array}{c}\text { North Texas } \\
\text { Phase 1 \& 2 } \\
\text { tests }^{3}\end{array}$ & $\begin{array}{c}\text { McGill } \\
\text { Phase 2 }^{\text {Tests }^{4}}\end{array}$ \\
\hline $\mathrm{R}_{\text {size }}$ & 1.05 & 1.05 & 1.05 & 1.05 \\
$\mathrm{R}_{\phi}$ & 1.43 & 1.43 & 1.43 & 1.43 \\
$\mathrm{R}_{\text {yield }}$ & 1.33 & 1.40 & 1.38 & 1.34 \\
$\mathrm{R}_{\text {sh }}$ & 1.00 & 1.00 & 1.00 & 1.00 \\
$\mathrm{R}_{\text {mech }}$ & 1.00 & 1.00 & 1.00 & 1.00 \\
$\mathrm{R}_{0}$ & 2.00 & 2.10 & 2.07 & 2.01 \\
\hline
\end{tabular}

${ }^{1}$ Shear wall data from test program by Ong-Tone \& Rogers [7].

${ }^{2}$ Shear wall data from test program by Balh \& Rogers [8].

${ }^{3}$ Shear wall data from test programs by Yu et al. [12] \& Yu \& Chen [13]; analysed by El-Saloussy \& Rogers [18].

${ }^{4}$ Shear wall data from test program by DaBreo \& Rogers [9]. 
Figure 1: a) Typical steel sheathed CFS framed shear wall during construction (photo courtesy of K. Bell, Simpson Strong-Tie Co. Inc.), and b) Single-storey shear wall test setup at McGill University.

a)

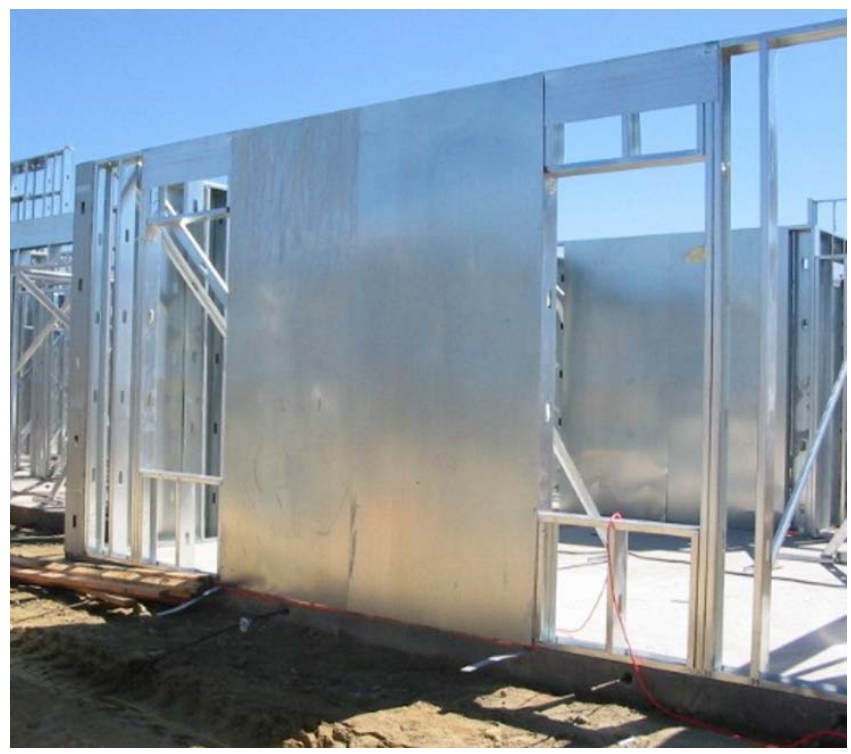

b)

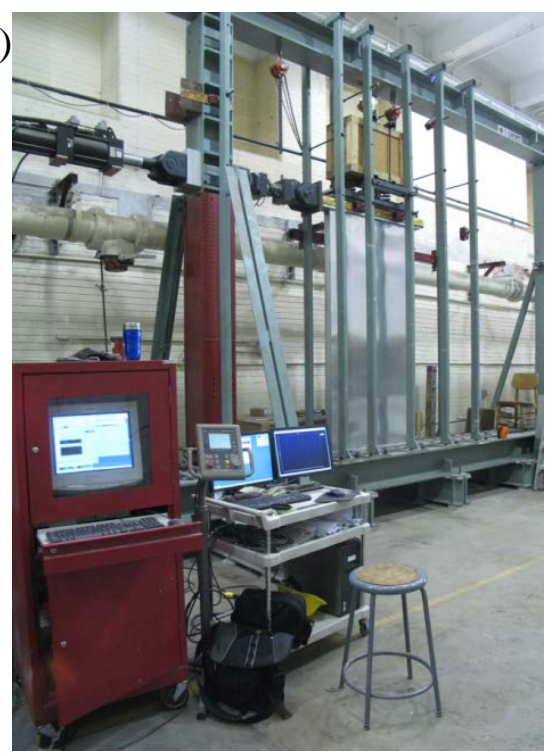


Figure 2 : Typical shear wall construction configurations; a) un-blocked wall, b) blocked wall, and c) multi-sheathing panel wall.

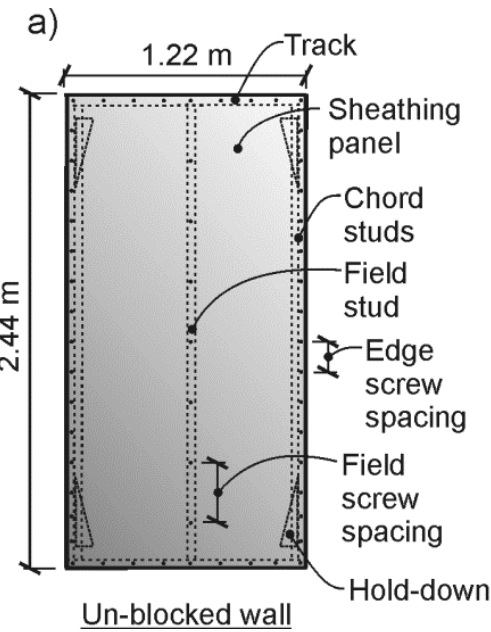

b)

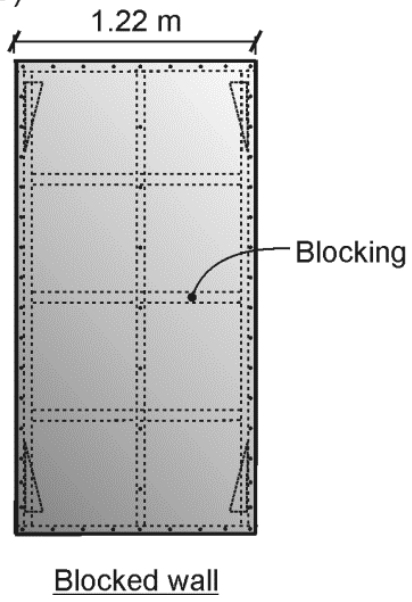

c)

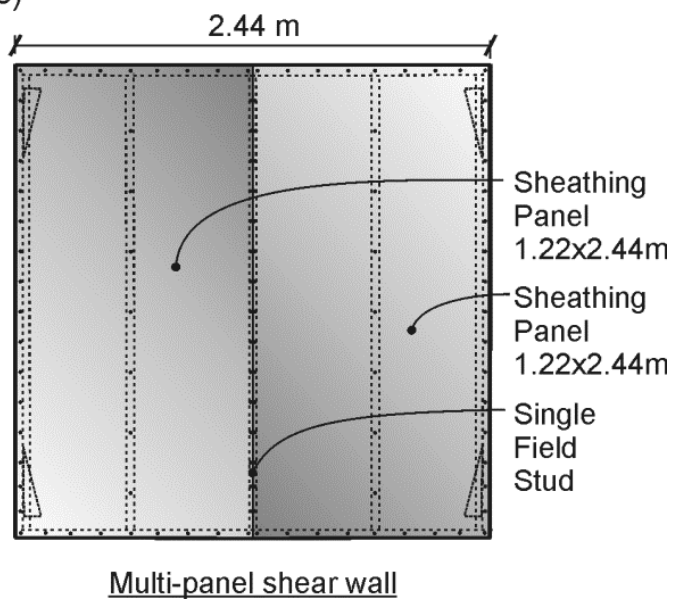


Figure 3 : a) Typical quarter-point blocking of CFS frame with full size track members, b) chord stud twisting damage in un-blocked wall, and c) typically sheathing connection damage in blocked wall.

a)

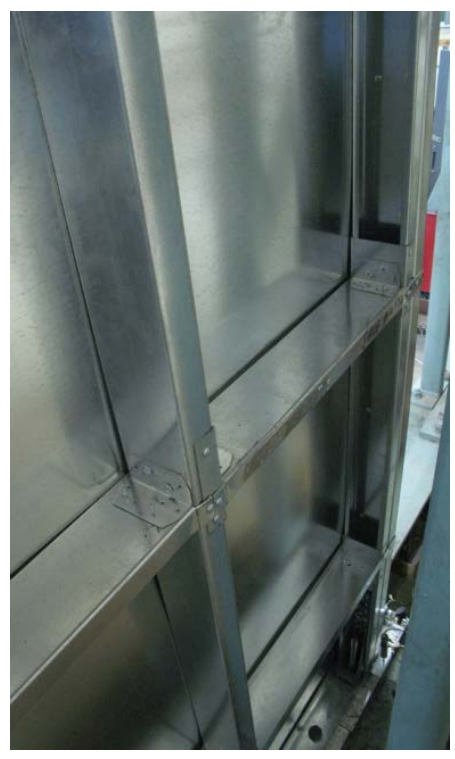

b)

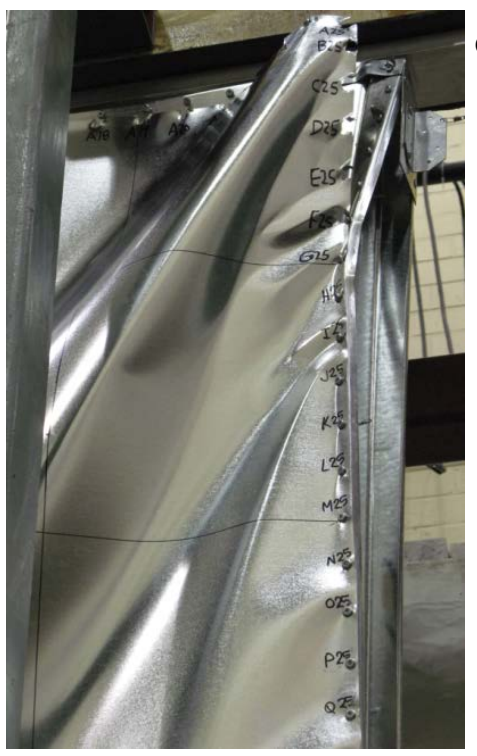

c)

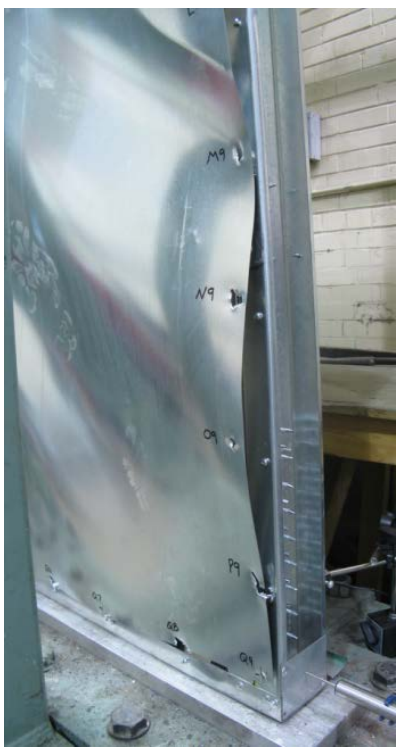


Figure 4 : Equivalent Energy Elastic-Plastic (EEEP) data analysis model for monotonic resistance $v s$. deflection test results

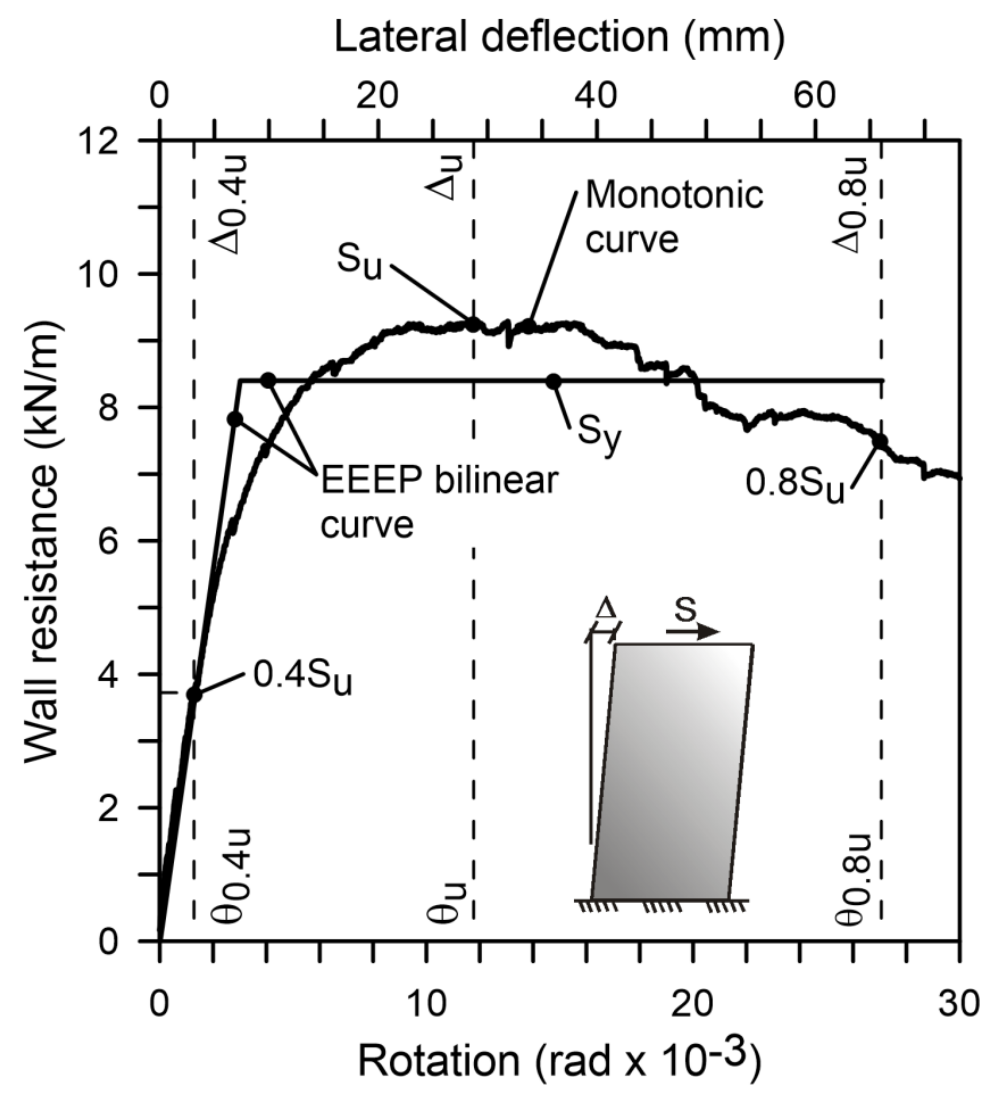


Figure 5: Example hysteresis, backbone and EEEP curves for reversed cyclic resistance vs. deflection test results

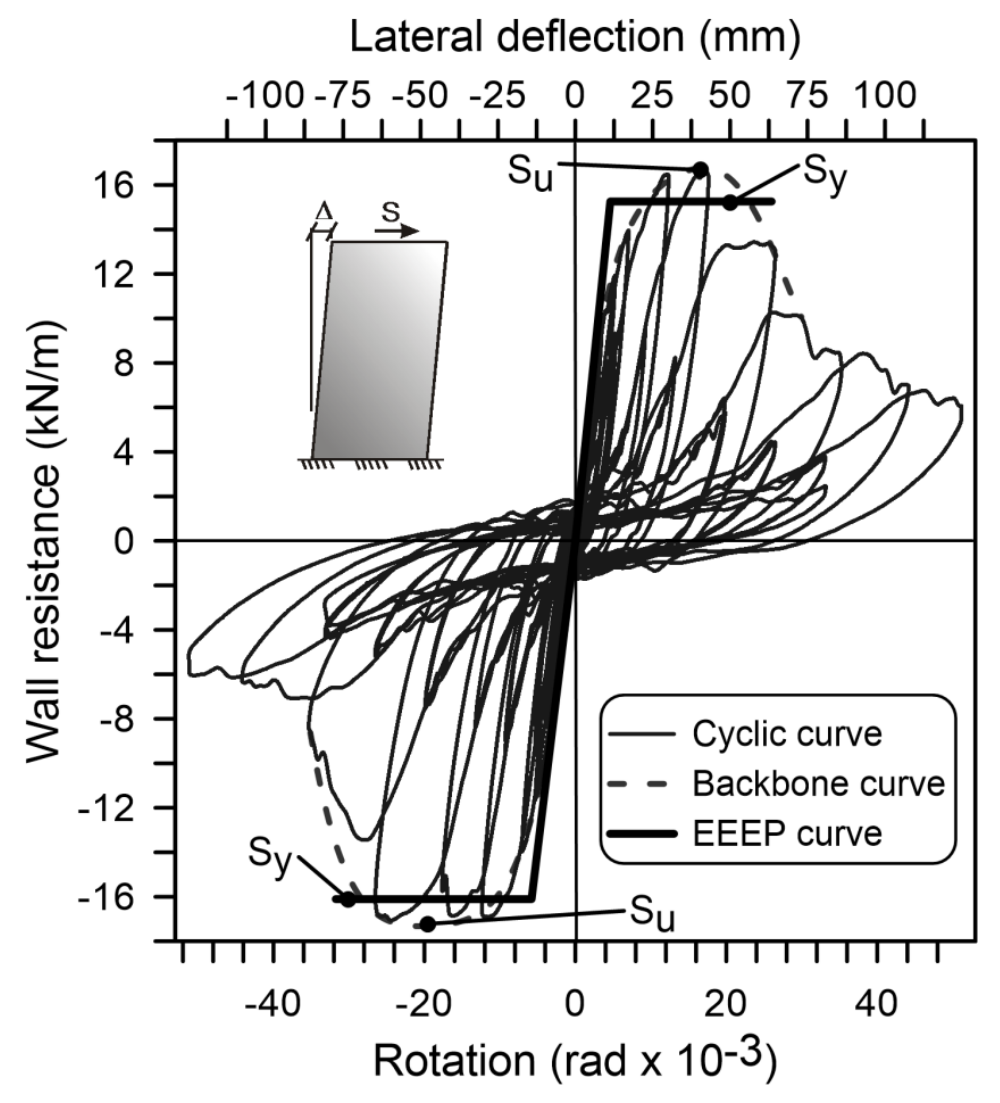


Figure 6: Example comparison of representative monotonic test and EEEP resistance vs. deflection curves for blocked and un-blocked shear walls of the same configuration.

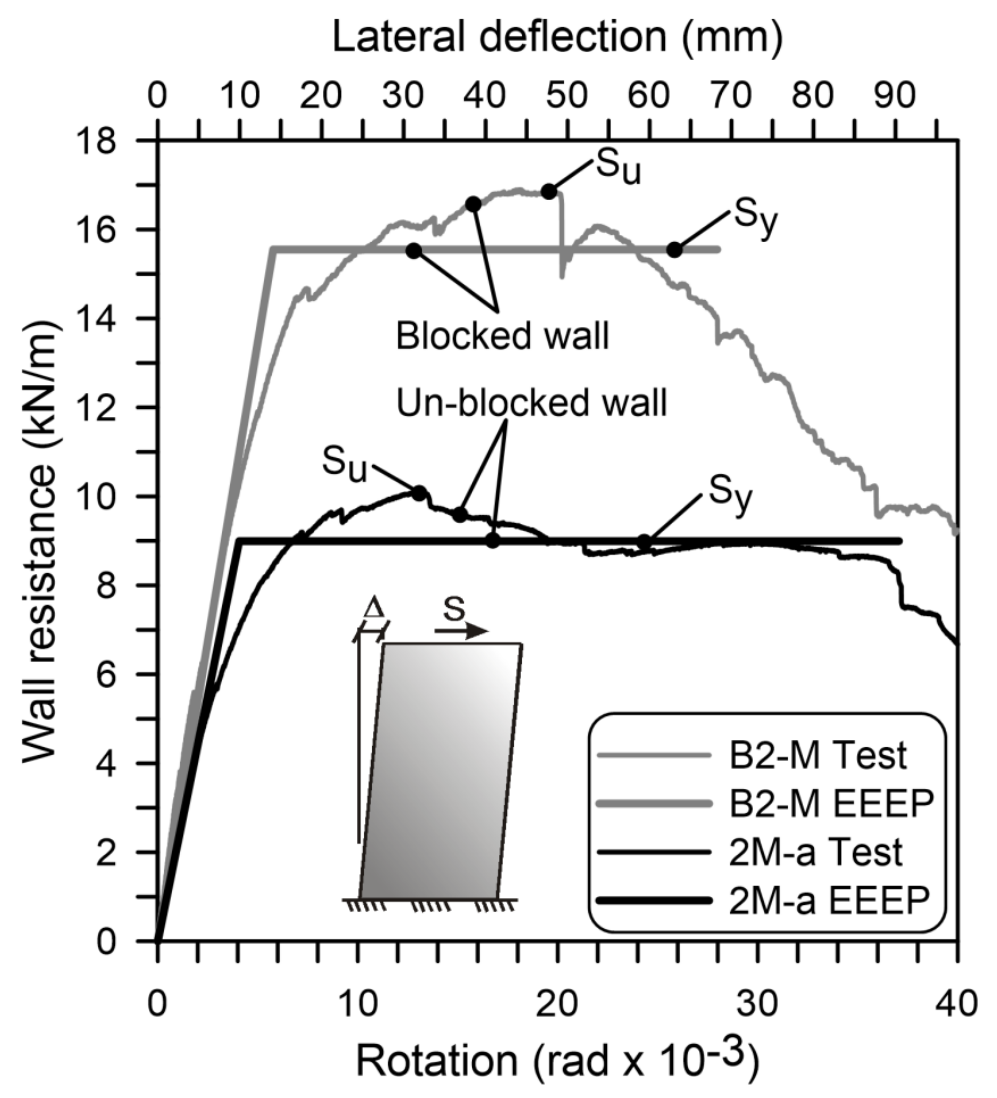


Figure 7: Example comparison of representative backbone (reversed cyclic test) and EEEP resistance vs. deflection curves for blocked and un-blocked shear walls of the same configuration.

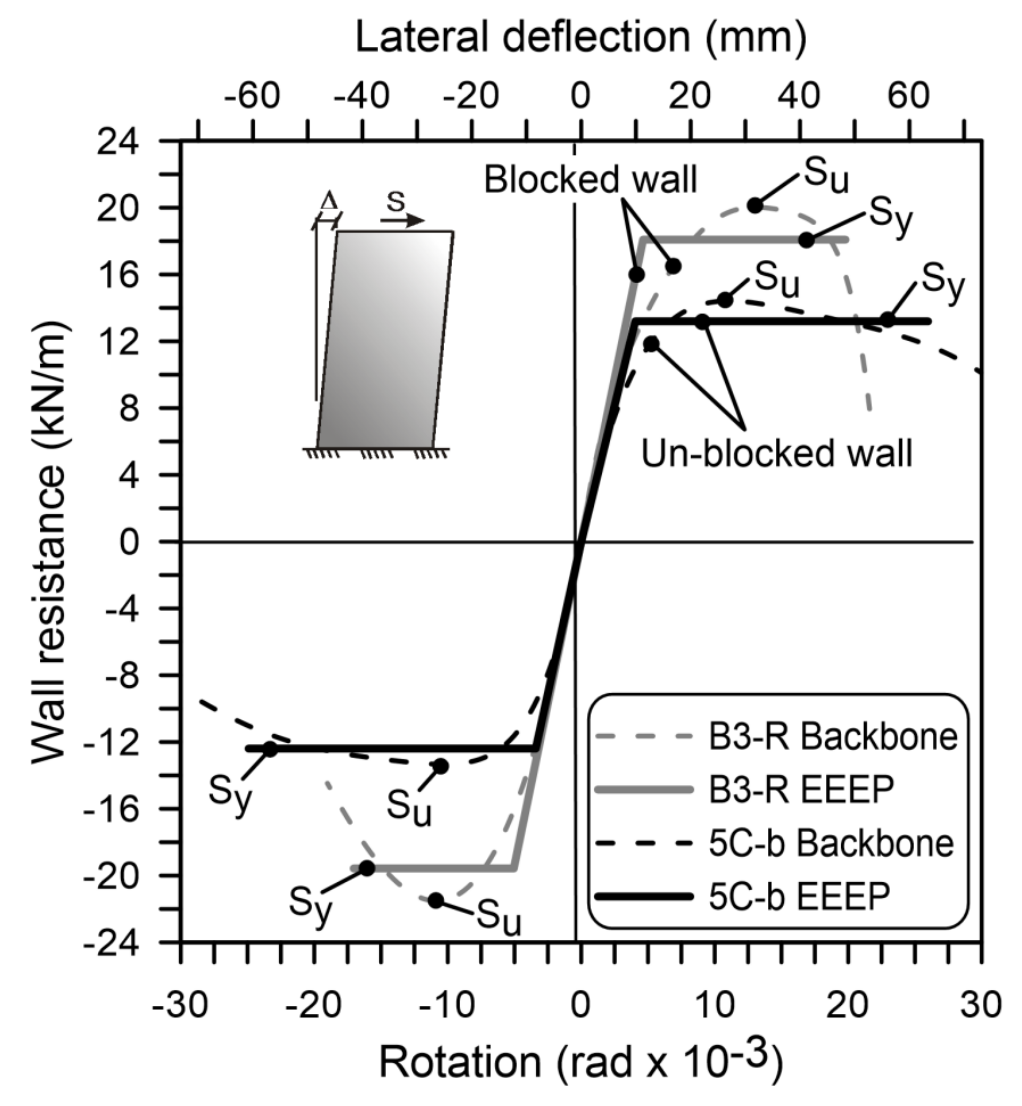


Figure 8: Factor of safety determined using limit states design information

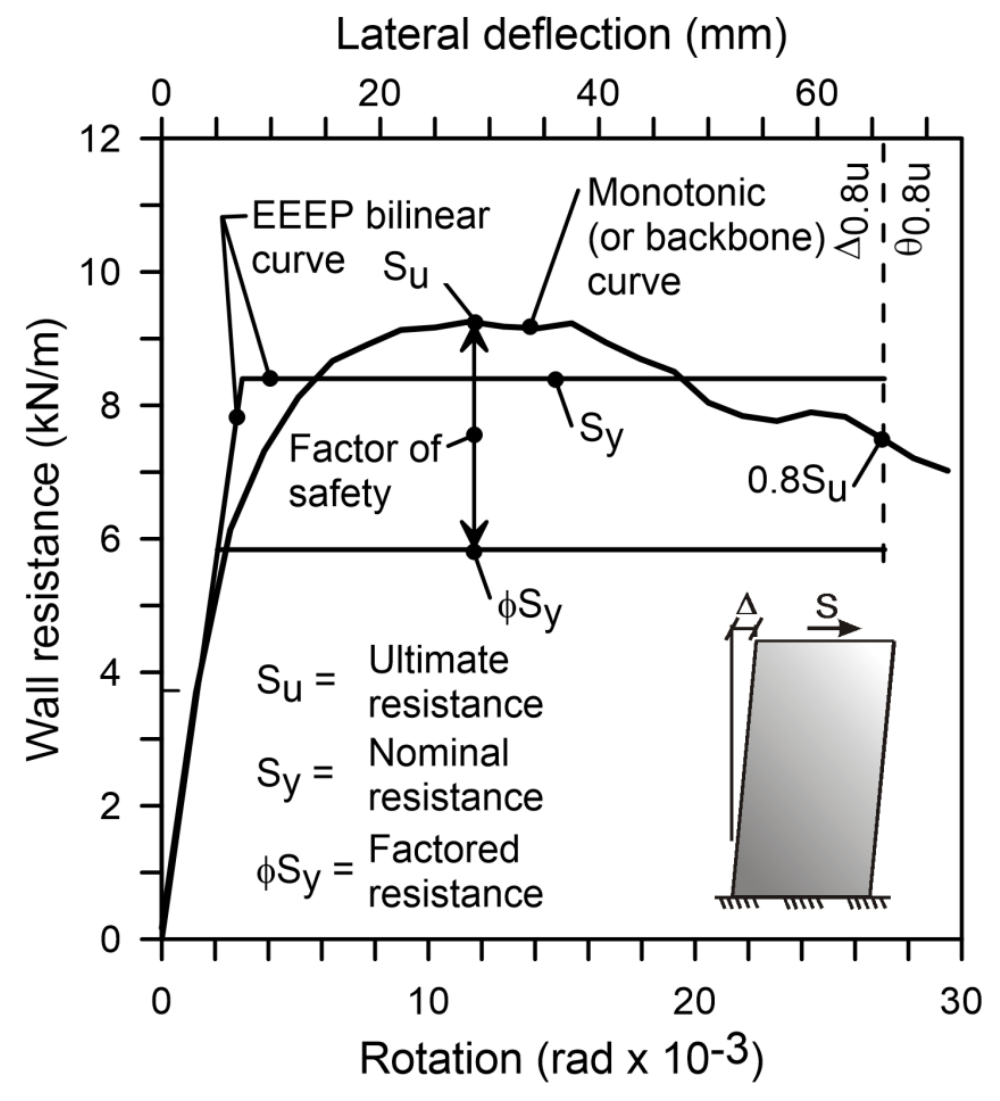


Figure 9: Over-strength of shear wall compared with nominal shear resistance

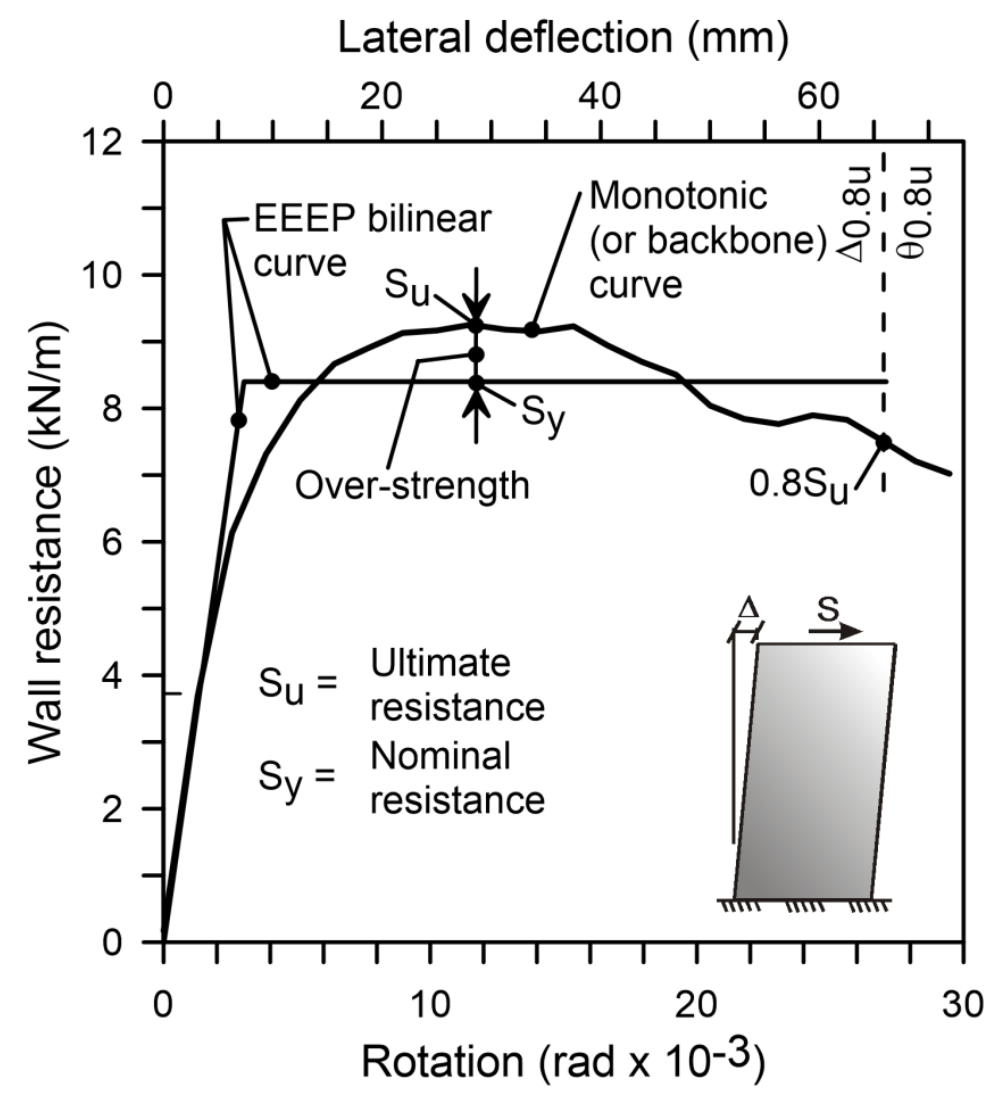

